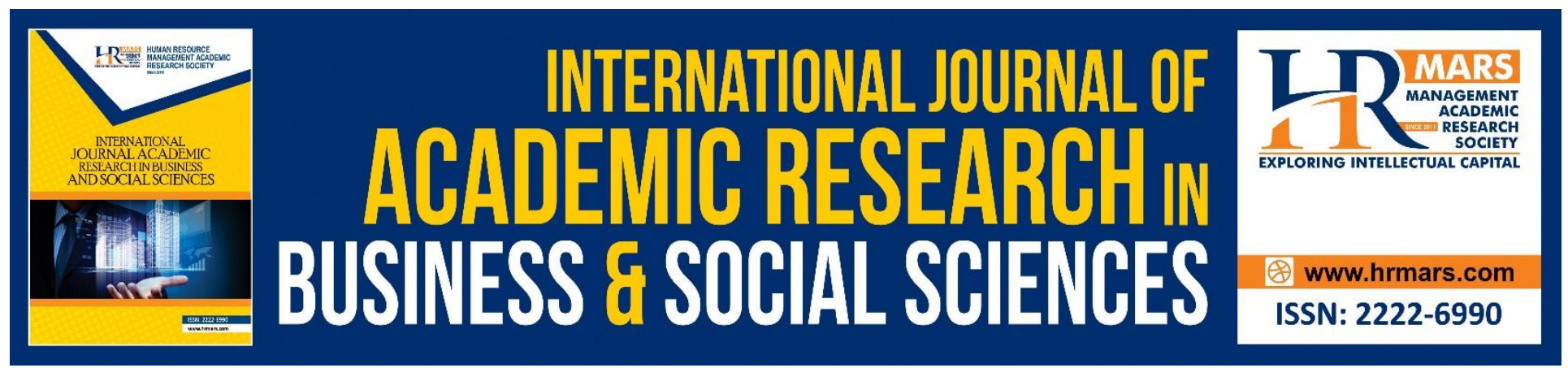

\title{
Public Receptivity Towards LGBT in Recent Times Malaysia: LGBT Perspectives
}

Collin Jerome, Su-Hie Ting, Yuwana Podin, Sharifah Sophia bt Wan Ahmad

To Link this Article: http://dx.doi.org/10.6007/IJARBSS/v11-i14/8943

DOI:10.6007/IJARBSS/v11-i14/8943

Received: 08 January 2021, Revised: 10 February 20210, Accepted: 28 February 2021

Published Online: 25 March 2021

In-Text Citation: (Jerome et al., 2021)

To Cite this Article: Jerome, C., Ting, S.-H., Podin, Y., \& Ahmad, S. S. bt W. (2021). Public Receptivity Towards LGBT in Recent Times Malaysia: LGBT Perspectives. International Journal of Academic Research in Business and Social Sciences, 11(14), 371-383.

Copyright: (c) 2021 The Author(s)

Published by Human Resource Management Academic Research Society (www.hrmars.com)

This article is published under the Creative Commons Attribution (CC BY 4.0) license. Anyone may reproduce, distribute, translate and create derivative works of this article (for both commercial and non-commercial purposes), subject to full attribution to the original publication and authors. The full terms of this license may be seen

at: http://creativecommons.org/licences/by/4.0/legalcode

Special Issue: Contemporary Business and Humanities Landscape Towards Sustainability, 2021, Pg. 371 - 383 http://hrmars.com/index.php/pages/detail/IJARBSS JOURNAL HOMEPAGE

Full Terms \& Conditions of access and use can be found at http://hrmars.com/index.php/pages/detail/publication-ethics 


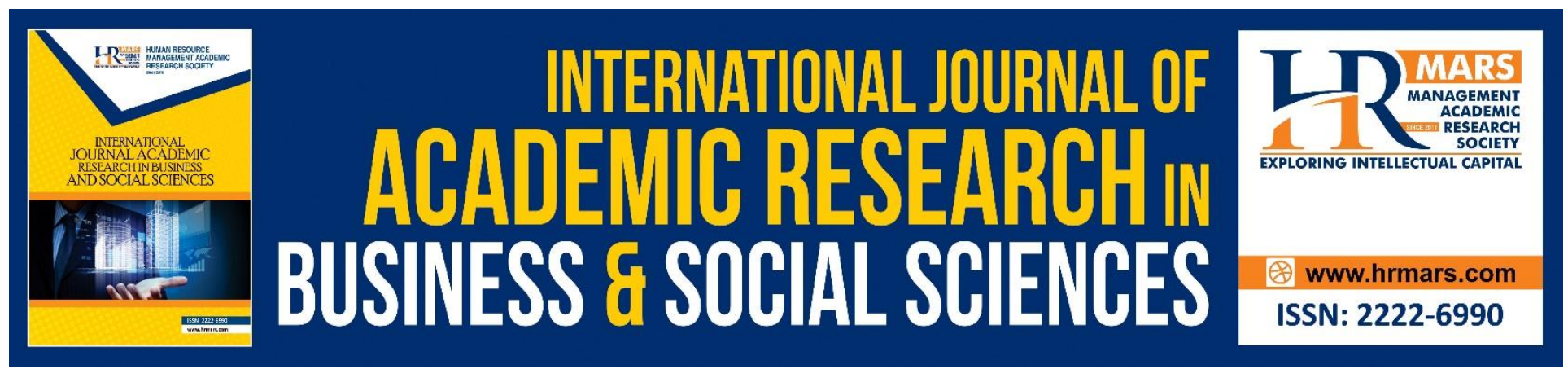

\title{
Public Receptivity Towards LGBT in Recent Times Malaysia: LGBT Perspectives
}

\author{
Collin Jerome, Su-Hie Ting \\ Faculty of Language and Communication, Universiti Malaysia Sarawak, Malaysia \\ Yuwana Podin \\ Institute of Health and Community Medicine, Universiti Malaysia Sarawak, Malaysia
}

\author{
Sharifah Sophia bt Wan Ahmad \\ Faculty of Social Science, Universiti Malaysia Sarawak, Malaysia \\ Email: jcollin@unimas.my
}

\begin{abstract}
The increasing visibility of LGBT communities has generated considerable public debate in Malaysia and many research studies have examined (and are currently examining) the subject matter. This article presents the findings of a qualitative study that aims to examine public receptivity towards LGBT in present-day Malaysia. Views from 15 LGBT individuals from Malaysia who consented to participate in the study were gathered via interviews and analyzed using Creswell's (2014) qualitative data analysis procedures. The findings show that the participants viewed public receptivity towards LGBT in Malaysia from two perspectives, despite their varying views on the subject matter based on their personal experiences: 1 ) religion and the cultural norms about gender and sexuality that are regulated within the ethnic groups the participants belong to continue to influence public receptivity towards LGBT; and 2) certain segments of the Malaysian public are showing receptivity towards LGBT in Malaysia as can be seen in the emergence of LGBT figures on social media, and their legions of followers who recognize and accept their non-normative gender or sexual identity. The findings have implications for current and future studies that examine the changing realities of Malaysia's LGBT communities in recent times.
\end{abstract}

Keywords: LGBT, Public Receptivity, Sanctions, Openness, Malaysia

\section{Introduction}

Although there is no denying that lesbian, gay, bisexual, and transgender (LGBT) communities have always been an indispensable part of the larger Malaysian society, identifying oneself as LGBT is not as easy as it seems where non-normative genders and sexualities are subject to social-legal condemnation (Ismail, 2001; Khartini, 2005; Teh, 2008). Malay Muslim LGBT, for instance, constantly 
experience difficulties in constructing and expressing their gender or sexual identities mainly because Islam forbids same-sex sexuality and therefore LGBT is generally perceived as un-Malay and unIslamic (Peletz, 1996; 2009; Zainon \& Kamila, 2011; Amelia \& Zaleha, 2017). Over the past several decades, Malaysian authorities have become more public and stern in their stance towards Malay Muslim LGBT (and Malaysian LGBT communities) through various laws and specific legislations (e.g., civil and Sharia). Such laws not only have a serious impact on their lived experiences and material conditions but also their sense of self and belonging in a country they call home (Jerome, 2020; Pang, 2015; Vinodh, 2018). However, the increased visibility of LGBT in today's digital and social media age cannot be ignored, and research on non-normative gender or sexualities in particular contexts in which homosexuality is officially sanctioned needs to take stock of this current development (Dzurik, 2018; GLSEN, 2013).

Malaysia is a case in point. The taboo on LGBT in the country is already 'dissipating' with growing segments of the public are beginning to talk about and invariably demonstrate their tolerance and acceptance of LGBT (Cheah \& Singaravelu, 2017; Jamal, Amat, Subhi, \& Faradi, 2018). This is attributed to, among others, the 'emergence' of LGBT figures (e.g., entrepreneurs, social media influencers, LGBT rights activists) whose fans or followers continue to support their causes and accept their gender or sexual identities. Research is especially needed to examine this sign of changing times in Malaysia, with a focus on sanctions and openness, and how they influence public receptivity towards LGBT in Malaysian society. The agents of socialization driving this change and promoting openness towards LGBT needs to be identified, and how the change is effected also needs to be researched. It is also important to understand how gender or sexual identity is articulated in a climate where LGBT rights are being asserted elsewhere in the world, and where cultural-religious and legal sanctions are prohibiting the coming-out process of lesbians, gays, bisexuals, and transgenders in specific socio-cultural contexts such as Malaysia.

With this in mind, the study presented in this article aims to examine present time public receptivity towards LGBT in Malaysia based on LGBT individuals' experiences living as LGBT in the country. More specifically, the study seeks to address the question

(1) what are their views about being LGBT in recent times Malaysia?

(2) what are their views about public receptivity towards LGBT, in light of religion and the ethnic group they belong to?

Before proceeding further, a review of some relevant literature review is presented to provide a brief overview of the topic.

\section{Literature Review}

As earlier mentioned, LGBT communities are part of the larger Malaysian society and their lived experiences have been extensively discussed in the literature from various perspectives. These, among others, include cross-dressing, same-sex attraction and sexual ambiguity in classical Malay texts (Farish, 2009), male homosexual relations during colonial rule in Malaya (Aldrich, 2003), pondan (effeminate men) as mak andam (bridal beautician) in Malay villages (Peletz, 1996), gay and lesbian couples (Ismail, 2001) and mak nyah (male transsexual) (Khartini, 2005; Teh, 2008). It is important to 
note that LGBT is a Western-derived term that has no equivalent in the local vernaculars. Terms such as lelaki lembut (soft men), songsang (inverted), bapuk, ah kua, mak nyah, pak nyah (specific forms of transgenderism), and wanita keras (hard women) are often used to describe individuals of nonnormative gender and sexuality locally (Pang, 2015). There are also individuals (e.g., heterosexual men in particular) who do not use any terms to describe their sexual attraction towards transsexuals and/or feminized gay men (Lim, 2015) - an example that reveals "the vague, fluid and unbounded ways many Malaysians view the myriad manifestations of non-normative gender and sexual expression" (Pang, 2015, p. 362).

Still, despite such a broad variety of local terms, LGBTs continue to be used by many Malaysians for numerous purposes (e.g., self-identification, self-representation, self-liberation) in various contexts and settings. However, in doing so, they often face difficulties and obstacles as a result of the religious, socio-cultural, and legal sanctions against their gender and sexual identities (Jerome, 2013; Peletz, 2009; Pang, 2015; Vinodh, 2018; Zainon \& Kamila, 2011). Homosexuality and other forms of nonnormative gender and sexuality in Malaysia, as many reports and research have shown, are subject to subject to criminalization, police harassment, and public prosecutions under both religious and civil laws. Reports and research also reveal that LGBT individuals and communities in general often face abuse, stigmatization, and discrimination because non-normative gender and sexuality contravene religious beliefs and moral codes, as well as the norms regulating masculinity and femininity in the larger Malaysian society.

Such sanctions (e.g., laws, rules, norms) have a profound impact on the existence and daily lives of the country's LGBTs as evidenced by, among others, the tensions and conflicts between 1) religion and sexuality, 2) individual needs and those of groups, 3) institutions and individuals, as well as 4) those within LGBT selves, among selves and between selves (Felix, 2016). The sanctions, however, are constantly dismantled by many LGBTs as a way to continue to live life on their terms through the adoption of various methods and strategies, including 1 ) reconciling the tensions between religion and sexuality (Bong, 2020), 2) implementing diverse self-adaptation/adjustment in navigating everyday lives (Shanon Shah, 2015), employing various communicative strategies for selfexpression (Cheah \& Singaravelu, 2017), and 4) speaking out against rights abuses of LGBT and advocating sexuality-related rights (Lee, 2013).

The proliferation of social media has facilitated further the above-mentioned ways, where many LGBTs turn to the Internet and social media in particular to or for 1) effectuating self-disclosure (Khadijah \& Ummu Syafiqah, 2020), overcoming stigmatization and discrimination mainly received offline (Jerome, 2019), 3) building resilience amidst adversity (Muhammad Naim \& Noor Mayudia, 2020), and 4) spreading LGBT movements (Muhammad Faiz, Wan Allef Elfi Danial, \& Zulkifli, 2019) to name a few. The recent resurgence of LGBT figures as earlier mentioned reveals a 'trend' of receptivity among some segments of the Malaysian public towards these individuals whose legions of fans, followers, and supporters support their causes and most importantly, acknowledge their gender and sexual identities.

Despite this recent development is worth noting, more needs to be known about its connection to public receptivity towards LGBT in recent times Malaysia: do sanctions against LGBT 
still have a stronghold on public receptivity towards the said individuals and communities? If they do, which sanction(s) are more or most dominant? If they do not, what drives public receptivity towards LGBT?

\section{Methodology}

Interviews were conducted involving a purposive sample of 15 LGBT individuals from major cities in Malaysia. There were more male (cisgender) participants (7 or $46.6 \%$ ) and most of the participants were aged between 35 to 39 ( 7 or $46.6 \%$ ). Five participants (33.3\%) identified themselves as gay, followed by $4(26.6 \%)$ lesbian, $3(20 \%)$ bisexual, and $3(40 \%)$ transgender. The participants represented the different ethnic groups in Malaysia, namely, the Malay (7 or $46.6 \%)$, Chinese (2 or 13.3\%), Indian ( 2 or $13.3 \%$ ), and Other Bumiputera (4 or $26.6 \%$ ). The majority were Muslims (7 or $46.6 \%$ ), and all participants resided in urban areas. The participants differed in terms of their educational status, employment, and as well as household income. Table 1 provides further information on the participants' demographic information.

\begin{tabular}{lll}
\hline Background Characteristics & N & $\%$ \\
\hline Gender Identity & 7 & \\
Male (cisgender) & 5 & 36.6 \\
Female (cisgender) & 3 & 20 \\
Transgender woman & & \\
Sexual Orientation & 5 & 33.3 \\
Gay & 4 & 26.6 \\
Lesbian & 3 & 20 \\
Bisexual & 3 & 20 \\
Heterosexual & & \\
Age & 2 & 13.3 \\
20-24 & 4 & 26.6 \\
25-29 & 7 & 46.6 \\
35-39 & 2 & 13.3 \\
45-49 & & \\
Ethnicity & 7 & 46.6 \\
Malay & 2 & 13.3 \\
Chinese & 2 & 13.3 \\
Indian & 4 & 26.6 \\
Other Bumiputera* & & \\
Religion & 7 & 46.6 \\
Islam & 2 & 13.3 \\
Buddhism & 4 & 26.6 \\
Christianity & 13.3 \\
Hinduism & & \\
Place of Residence & & \\
Urban & 100.00 \\
Education & & \\
Degree or higher (include Advanced Diploma) & 7 & 46.6 \\
\end{tabular}


INTERNATIONAL JOURNAL OF ACADEMIC RESEARCH IN BUSINESS AND SOCIAL SCIENCES

Vol. 11, No. 14, Contemporary Business and Humanities Landscape Towards Sustainability. 2021, E-ISSN: 2222-6990 @ 2021 HRMARS

\begin{tabular}{lll} 
Diploma & 8 & 53.3 \\
Employment & & \\
Employed & 7 & 46.6 \\
Self-employed & 6 & 40 \\
Full-time/Part-time Student & 2 & 13.3 \\
Monthly Household Income & & \\
RM9,620 and above & 5 & 33.3 \\
RM4360-9,619.00 & 5 & 33.3 \\
Below RM4,360 & 5 & 33.3 \\
\hline
\end{tabular}

Notes: *2 Iban and 2 Bidayuh

Table 1: Demographic Data

Since real, national data on the LGBT population are nonexistent and the constraint in finding willing LGBT individuals to participate in research, a small sample size is adequate as it allows the gathering of extensive, much-needed information from each participant following the research aim and objectives.

The interviews were conducted in English, with the occasional use of Malay within different interview settings or venues based on the participants' respective choices. At the beginning of the interview, the researchers explained the full purpose of the study and administered full consent procedures. The researchers assured the participants of confidentiality regarding disclosed information and explained that their involvement was voluntary, and they could withdraw from participation at any time. Audiotaping began once the consent was obtained and continued throughout the researcher-participant conversation. The participants were well-spoken, perceptive, and articulate in expressing their views and experiences regarding the public receptivity towards LGBT in Malaysia. Table 2 shows the questions that were asked during the interview session.

1. When did you first realize that you have a different sexual orientation from others?

2. How did you manage, and present your sexual orientation to others?

3. How do you feel about being an LGBT person living in this society?

4. What/Who influenced your views and attitudes towards LGBT?

5. Do you think the public accepts LGBT in this country?

6. Does your ethnic group accept LGBT? Why?

7. Does your religion accept LGBT? Why?

Notes*The questions were adapted from two other studies on LGBT Malaysians: the studies by Cheah and Singaravelu (2017), and Diyana Mastura, Muhammad Alif, Muhammad Muaz and Noraniqnuri (2019).

Table 2: Interview Questions*

The interviews were transcribed verbatim and analyzed following Creswell's (2014) qualitative analysis procedures in examining interview data. These procedures include 1) organizing and preparing the data for analysis; 2) reading all the data, 3) coding the data by segmenting and categorizing information; and 4) generating themes from the coding process. Creswell's (2014) 
validity strategy, namely, member checking, was employed to reduce bias and ensure the accuracy of findings. Member checking was conducted in the study by showing summaries of findings to the participants and asked them whether the findings accurately reflected their personal experiences.

\section{Results and Discussion}

The analysis of the interview data revealed that the participants held different views concerning public receptivity towards LGBT in Malaysia based on their personal experiences. The results are discussed based on the following themes that emerged from the analysis of the interview data.

\section{Views on Self-Realization of Being LGBT}

Findings show that the participants reported different experiences of self-realization of being LGBT as they indicated the different points in their lives when they realized they possessed non-normative sexual orientations "at an early age" (e.g., adolescence) to "at a later stage in life" (adulthood). Other participants gave varied responses, from "Always knew I like both sexes", I enjoy experimenting with my sexuality" to "Not sure, but I knew I developed feelings for both". Most participants came out to their "close friends" first (e.g., LGBT or non-LGBT), while others revealed that they came out to their family (e.g., parents, siblings, extended family). Others, however, mentioned that they were either "not out or not sure they are out (yet)". Only one participant admitted that he first came out to those whom he dated, since he was (and still is) "new to being gay".

These experiences, as the findings reveal, affected, or influenced how they managed and presented their sexual identities to others. Those who came out to their close friends would only reveal or express their sexual identities to this group of people, and it often went effortlessly or without saying as they understood each other well. The same applies to those who came out to their families who recognized and accepted their LGBT children. Others, however, resorted to different ways of managing and presenting their sexual identities, from "put(ting) pretense, keep(ing) things, hid(ing) things", "reveal it to those who I want to date" and "I will only say that I'm gay online". As the following lines taken from the interviews show:

I only reveal my identity when I am with others who are of the same sexual orientation - a gay Chinese man in his mid-20s

I identify myself as a trans woman to those I know and to others in other settings, such as my workplace and the public

- a transgender Malay woman in her late 40s

I have to put up pretense daily, keep things, hide things. It's the fear of being found out really - a lesbian Malay woman in her mid-30s

I will only say that I'm gay online. This helps a lot when I get along with other gay men online - A gay Iban man in his mid-30s 
Findings show that the majority of participants felt positive about being an LGBT person living in Malaysia. This feeling was fortified by their belief that certain segments of the public (e.g., peers, family members, work colleagues) recognized and accepted them as LGBT. Other participants felt otherwise with their reasons and experiences, from "a bit tricky (because) being gay is still not accepted", "Not as easy as you think (because) society still cannot accept", "Feels like threading water (with) so much effort put on pretense", and "people don't target bisexuals (because) they can't guess". As the following lines taken from the interviews show:

It has been great so far. I get the support that I need. Not everyone in our society can accept people like us, but things have changed as we are more visible now and more people are accepting us - a transgender Malay woman in her mid-20s

So far okay, probably because I surround myself with people of the same kind. I don't care much what others say because it all depends on the people you hang out with

- a gay Chinese man in his mid-20s

Life is hard. Feels like threading water, so much effort put on pretense, coz I am lesbian and Malay. And you know it's something that my community cannot accept

- a lesbian Malay woman in her mid-30s

The views, as the findings reveal, were shaped by several factors. Most participants cited close peers and family members, as well as information they gained about LGBT through various sources (e.g., books, the Internet, social media) that influenced their views on being LGBT in Malaysia. Other participants reported that their views and attitudes were shaped by their own experiences of being in sexually intimate relationships with other LGBT and friendship with senior or more experienced LGBT persons. As the following lines taken from the interviews show:

Oh many, books, TV, movies when I was younger, then own experiences being in a relationship taught me how to be a better person

- a lesbian Iban woman in her late 40s

Own self-reading of gay lives, also stories or experiences from older gay guys or gay friends - a gay Bidayuh man in his late 40s

People in my life, like my family, close friends, and also older trans who are like my older sisters or teachers. These people are important to me and I continue to learn life experiences from them. a transgender Malay woman in her later $40 \mathrm{~s}$

Views on Public Receptivity Towards LGBT in Light of Religion and Ethnic Groups

Findings show that strong emotional responses were evident among most participants when they were asked whether their respective ethnic groups and religions accepted LGBT. Those of Malay ethnicity and Islamic faith claimed that LGBT was a sin and went against the family and community norms. The views were echoed by participants of Iban or Bidayuh ethnicity, and Christian faith who 
cited that LGBT contravened the religious tenets and practices of Christianity. As the following lines taken from the interviews show:

No, Malays don't accept people like us because of our religion

- a lesbian Malay woman in her early 20s

No, because homosexuality is a sin in Christianity. Most Ibans are Christians and they believe that it goes against religion

- a gay Iban man in his mid-30s

Two Chinese participants, who professed Buddhism, believed that not all members of their community could accept LGBT due to parental expectations. What mattered was that they must do good things in life, and be rewarded in return. As the following lines taken from the interviews show:

Not all Chinese can accept, because of the expectations to be a daughter or son in the family. I cannot say whether being lesbian goes against Buddhism. All I can say is that if you do good things in life, that is enough and that is all that matters

- a lesbian Chinese woman in her late 20s

I'm not so sure, I can't speak on behalf of other LGBT from the Chinese community. Do good in life, don't make trouble, mind your own life - these are more important for me.

- a gay Chinese man in his mid-20s

Participants of Indian ethnicity and who professed Hinduism had different views; one said it was not easy due to the expectations of being a man in the family and community, while the other said he did not think much about it. As the following lines taken from the interviews show:

Being gay is not always easy. There are a lot of expectations to be a man in my family and my community, that one has to fulfill.

- a gay Indian man in his late 20 s

I know that I am expected to get married and raise my own family and continue to carry out my duties as a son to my parents, like what they have done for their parents.

- a bisexual Indian man in his mid-40s

Nevertheless, the strong emotional responses did not dampen their strong positive responses to the question of whether they accepted themselves as LGBT, with most of them claiming "Yes, I do", "Yes, I am one of them" and "I accept myself for being. ..". As the following lines taken from the interviews show:

I accept myself for being gay, even though it is hard to get acceptance from your family

- a gay Indian man in his later 20s 
INTERNATIONAL JOURNAL OF ACADEMIC RESEARCH IN BUSINESS AND SOCIAL SCIENCES

Vol. 11, No. 14, Contemporary Business and Humanities Landscape Towards Sustainability. 2021, E-ISSN: 2222-6990 @ 2021 HRMARS

If you are talking about accepting myself, it's a yes. If you are talking about accepting myself within the LGBT community, it's also a yes. I am one of them!

- a lesbian Iban woman in her late 40s

Others, however, gave varied answers, from "We bis(sexuals) are like invisible, all cares about GLT, not B" and 'Transgender community, yes, but I'm not sure about gay or lesbian community". As the following lines taken from the interviews show more of the participants' varied responses:

We bis are like in the middle because we are like nobody's in the local LGBT scene - a bisexual Malay woman in her mid-30s

I am accepted within my transgender community. But I'm not sure about being accepted by the gay or lesbian community. I always feel that they do not understand us because of our differences.

- a transgender Malay woman in her mid-20s

Several points can be gleaned from the above findings. First, what it means to be LGBT for the participants, and the process of being and becoming an LGBT person is complex. This process, as many scholars have pointed out, differs from one individual to another, and varies in terms of actions, impacts, and accomplishments (Herdt, 2013; Rudoe, 2014). A possible explanation is that as individuals progress through the developmental stages towards achieving an integrated LGBT identity, they do so fluidly rather than linearly, and the coming-out events are affected by this, alongside diverse factors such as gender, race, age, religion, and so on. Greenfield (2008), among many scholars, posit that becoming LGBT is "a challenging, dynamic and lifelong experience" due to the confluence of diverse influences such as life stages, events, and experiences, as well as personal motivations and relationships with others - all of which "create different contexts and results in a wide variety of experiences for both the person coming out and for those in whom the LGBT person confides" (pp. 45, 56-57).

Second, religious and cultural norms about gender and sexuality are the dominant sanctions that still influence public receptivity towards LGBT in Malaysia. This comes as no surprise because religion and culture were mostly cited by LGBT Malaysians in past research, especially the ways religious and cultural norms influenced their experiences of being and becoming LGBT in society (Zainon \& Kamila, 2011; Jerome. 2013; 2020). What is more is that these norms are shaped by and regulated through various social institutions, namely, family, community, and religion. However, such norms can be dismantled and overturned through the participants' sense of 'openness' (e.g., in reinterpreting those norms and sanctions) and the openness' of those whom they confided. This is observed in the responses such as "As long as I do good things in life, that is all that matters", "It's between me and God", and "My family has been supportive of me being trans at an early age". However, unlike the findings reported in previous studies on LGBT in Malaysia, none of the participants in the current study mentioned the laws (e.g., federal, state, local) that criminalize LGBT in Malaysia. This is intriguing, on the basis that the participants as LGBTs in recent times Malaysia may not only have developed a sense of resistance against these laws, but also a sense of 'adaptability' by co-existing with such laws through the various maneuverings in their lives (e.g., 
strategies for self-identification and self-expression in public and private spaces, reinterpreting norms and sanctions to live life on their terms).

Finally, public receptivity towards LGBT persons and communities in Malaysia was described by the participants in various terms including "openness", "tolerance", "acceptance", "acknowledgment", and "recognition". Many of them maintained that a sense of openness within oneself as demonstrated by their self-acceptance of being and becoming LGBT was important, and as the first step towards public receptivity. Most of them pointed out that "openness" was evident in some segments of the general public including their peers, work colleagues, and family members. What is more is that these segments also include the fans, followers, commentators, and supporters of local LGBT figures that have emerged in recent years. Some participants in the study cited names of famous cosmetic/beauty entrepreneurs, Instafamous and social media influencers, as well as LGBT rights activists who have made (and continue to make) headlines in public discourse as a result of their strong presence in social media. Although the participants argued that these 'famous' social media LGBT figures may not represent the larger LGBT population in Malaysia, they agreed that these figures had somewhat altered the public's general view on LGBTs' existences and presence, which can no longer be ignored in today's internet-driven society - a point that would be worth investigating in future research. While this development shows the signs of changing time in a country where homosexuality and nonnormative gender and sexuality remain subject to various sanctions, more needs to be known about the views of non-LGBT Malaysians on the subject matter, which may shed further insights into whether the sanctions still exert a stronghold over their opinions about LGBT.

\section{Conclusion}

The main aim of this article has been to examine public receptivity towards LGBT in Malaysia, with a specific focus on the views of LGBT individuals on the subject matter based on their personal experiences. The analysis of the interview data shows that public receptivity continues to be influenced by religion and cultural norms about gender and sexuality, and how these norms are practiced by the ethnic groups that the LGBT participants belong to. The analysis also shows that these sanctions can be dismantled and overturned by the sense of openness within LGBT persons' selves, and the openness that comes from others whom they confide including their peers and family members.

Although the data reveals that some segments of the public have shown receptivity towards LGBT as evidenced by the fans and followers of local social media LGBT figures, more needs to be known about the impact that this level of receptivity may have on the lived experiences and material conditions of other LGBT individuals in recent times Malaysia, if we consider the differences within the LGBT community (e.g., openness and identity disclosure; generational gap and subcultures) and other influencing factors as such socio-economic status, geography (rural/urban), levels of technology and social media use (high/low; users/non-users) and educational background (high/low). The fact that the laws against LGBT were not mentioned by the participants in the study as one of the dominant sanctions, is worthy of investigation, considering that such laws have been frequently cited and became a source of tension among LGBT Malaysians in previous research studies. 
Finally, what has been shown here reflects a glimpse of the dominant sanctions and level of receptivity towards LGBT based on the views of LGBT persons living in Malaysia. Due to the small sample size, the article acknowledges the results are not representative of individuals or members of the larger LGBT communities in the country whose voices are equally important and deserving of mention. At most, the results provide a basis for further studies that could provide a more nuanced understanding of LGBT in recent times Malaysia.

\section{Acknowledgement}

The study presented in this article is funded by the Ministry of Education under the Fundamental Research Grant Scheme (F09/FRGS/1874/2019).

\section{References}

Aldrich, R. (2003). Colonialism and homosexuality. London: Routledge.

Bong, S. A. (2020). Becoming queer and religious in Malaysia and Singapore. London: Bloomsbury Academic.

Cheah, W. H., \& Singaravelu, H. (2017). The coming-out process of gay and lesbian individuals from Islamic Malaysia: Communication strategies and motivations. Journal of Intercultural Communication Research, 46(5), 401-423.

Dzurik, A. (2018). Social media, iPhones, iPads, and identity: Media impact on the coming-out process for LGBT youths. In C. Stewart (Ed.), Lesbian, gay, bisexual, and transgender Americans at risk: Problems and solutions (pp. 185-204). Santa Barbra: ABC-CLIO.

Noor, F. (2009). What your teacher didn't tell you: The Annex lectures, Vol. 1. Petaling Jaya: Matahari Books.

Felix, M. (2016). Gay identity construction of ten Muslim male undergraduates in Penang, Malaysia: A phenomenological qualitative study. Asia-Pacific Social Science Review, 16(2), 113-119. Retrieved from http://apssr.com/wp-content/uploads/2018/04/9.Research-Brief_Felix120216.pdf

Greenfield, J. (2008). "Coming Out: The process of forming a positive identity." In H. J. Makadon, K. H. Mayer, J. Potter, H. Goldhammer, \& K. Mayer (Eds.), The Fenway guide to lesbian, gay, bisexual, and transgender health (pp. 45-76). Philadelphia: American College of Physicians.

GLSEN. (2013). Out online: The experiences of lesbian, gay, bisexual, and transgender youth on the Internet. New York, NY: GLSEN. Retrieved from https://www.glsen. org/sites/default/files/Out\%200nline\%20FIN AL.pdf

Herdt, G. (2013). Gay and lesbian youth. New York: Routledge.

Baba, I. (2001). Gay and lesbian couples in Malaysia. In G. Sullivan \& P. A. Jackson (Eds.), Gay and lesbian Asia: Culture, identity, community (pp. 143-163). New York: Harrington Park Press.

Jerome, C. (2013). Queer Malay identity formation. Indonesia and the Malay World, 41(119), 97-115. Doi: 10.1080/13639811.2012.757875

Jerome, C. (2019). The right to be me, queerly, cyberly: Cybercrime and queer individuals in Malaysia. In Y. H. Khoo \& D. Simandjuntak (Eds.), Exploring the nexus between technologies and human rights: Opportunities and challenges in Southeast Asia (pp. 150-184). Bangkok, Thailand: SHAPE-SEA.

Jerome, C. (2020). A place I could call my own: Queer Malays and the meanings of 'home'. Indonesia and the Malay World, 48(141), 247-260. Doi: 10.1080/13639811.2020.1751948 
Slamah, K. (2005). The struggle to be ourselves, neither men nor women: Maknyahs in Malaysia. In G. Misra \& R. Chandiramani (Eds.), Sexuality, gender, and rights: Exploring theory and practice in South and Southeast Asia (pp. 98-112). London: Sage.

Lee, J. C. H. (2013). Sexuality rights activism in Malaysia: The case of seksualiti Merdeka. In M. Ford (Ed.), Social activism in Southeast Asia (pp. 170-186). Oxon and New York: Routledge.

Lim, D. C. L. (2015). Visualizing the invisible: Social constructions of straight-identified men who have sex with transsexuals and feminized gay men on/off Malaysian film. Studies in Gender and Sexuality, 16(3), 183-203. Doi:10.1080/15240657.2015.1073047

Alil, M. N. M., Mothar, N. M. (2020). Discourses on Twitter contribute to the concept of resilience in the LGBT community in Malaysia. ESTEEM Journal of Social Sciences and Humanities, 5, 2747.?

Pang, K. T. (2015). Sexual citizenship in conflict. In M. L. Weiss (Ed.). Routledge handbook of contemporary Malaysia (pp. 361-374). Oxon: Routledge.

Peletz, M. G. (1996). Reason and passion: Representations of gender in a Malay society. Berkeley: University of California Press.

Peletz, M. G. (2009). Gender pluralism: Southeast Asia since early modern times. New York: Routledge.

Rudoe, N. (2014). "Out in Britain: The politics of sexuality education and lesbian and gay teachers in schools." In H. Gray \& Gray, E. (Eds.), Queer teachers, identity and performativity (pp. 60-74). New York: Palgrave McMillan.

Sidik, S. S. M. (2015). The making of a gay Muslim: social constructions of religion, sexuality, and identity in Malaysia and Britain. (Unpublished Ph.D. thesis), King's College London, University of London, United Kingdom.

Teh, Y. K. (2008). Politics and Islam: factors determining the identity and status of male-to-female transsexuals in Malaysia. In F. Martin, P.A. Jackson, M. McLelland \& A. Yue (Eds.), AsiaPacifiQueer: rethinking genders and sexualities (pp. 85-98) Illinois: University of Illinois Press.

Pillai, V. (2018). No way we'll recognize gay rights in Malaysia, says Dr M. Free Malaysia Today. Retrieved from https://www.freemalaysiatoday.com/category/ nation/2018/09/12/no-waywell-recognise-gay-rights-in-Malaysia-says-dr.m/

Shamsudin, Z., \& Ghazali, K. (2011). A discursive construction of homosexual males in a Muslimdominant community. Multilingua (Special Issue) - Journal of Cross-Cultural and Interlanguage Communication. 30(3-4), 279-304. 